\title{
“The Blank Page" and The Issues Of Female Creativity
}

\author{
SUSAN GUBAR
}

I am indebted to Sandra M. Gilbert for her insights and encouragement on this paper.

When the "Mona Lisa" was stolen from the Louvre in Paris in 1911 and was missing for two years, more people went to stare at the blank space than had gone to look at the masterpiece in the 12 previous years.

-BARBARA CARTLAND, Book of Useless Information

"The female genital, like the blank page anticipating the poem, is an absence, a not me, which I occupy."

-SANDra McPherson, "Sentience," The Year of Our Birth

Consider for a moment Ovid's story of Pygmalion: a king, shocked at the vices of the female disposition, creates a beautiful statue, significantly an ivory statue white as snow, with which he falls in love. Pygmalion brings his lovely statue presents, dresses it, bedecks it with jewels, fondles its curves, takes it to bed, and prays to Venus that his wife be (or be like) his "ivory girl." When he feels the ivory under his fingers soften, "as wax grows soft in sunshine, made pliable by handling," Pygmalion is astonished with joy: "It is a body!"2 Not only has he created life, he has created female life as he would like it to be-pliable, responsive, purely physical. Most important, he has evaded the humiliation, shared by many men, of acknowledging that it is he who is really created out of and from the female body.

Our culture is steeped in such myths of male primacy in theological, artistic, and scientific creativity. Christianity, as feminist theologians have shown us, is based on the power of God the Father, who creates the natural world of generation out of nothing. ${ }^{3}$ Literary men like Coleridge, Shelley, Keats, and Ruskin describe the author as priest, prophet, warrior, legislator, or emperor,

\footnotetext{
${ }^{1}$ Reprinted by permission of The University of Chicago. Originally published in Critical Inquiry Vol. 8, No. 2, Writing and Sexual Difference (Winter, 1981): 243-263.

${ }^{2}$ Ovid, Metamorphoses, trans. Rolfe Humphries (Bloomington, Ind., 1955), pp. 241-43.

${ }^{3}$ See Mary Daly, Beyond God the Father (Boston, 1973), and Womanspirit Rising: A Feminist Reader in Religion, ed. Carol P. Christ and Judith Plaskow (San Francisco, 1979).
} 
reinforcing the idea most lucidly articulated by Gerard Manley Hopkins that "the male quality is the creative gift." 4 The example of scientific overreachers from the Faust of Marlowe and Goethe and Mann to the most recent DNA biologists implies that scientific ingenuity also seeks to usurp the generative powers of the womb, even as it tries to re-create the female in the male's image. But if the creator is a man, the creation itself is the female, who, like Pygmalion's ivory girl, has no name or identity or voice of her own. Margaret Atwood's prose poem about two boys who construct a woman out of mud ("She began at the neck and ended at the knees and elbows: they stuck to essentials") seems far removed from Ovid's ivory girl. Yet the boys continually "repair her, making her hips more spacious, enlarging her breasts with their stone nipples," as they make use of "her brown wormy flesh" ("They would take turns, they were not jealous, she preferred them both"): ${ }^{5}$ both the ivory girl and the mud woman are products of the male imagination, objects created for the use of men. As Simone de Beauvoir has demonstrated in The Second Sex, the phallus as the transcendent incarnate turns woman's self into an object, an other. ${ }^{6}$

Woman is not simply an object, however. If we think in terms of the production of culture, she is an art object: she is the ivory carving or mud replica, an icon or doll, but she is not the sculptor. Lest this seem fanciful, we should remember that until very recently women have been barred from art schools as students yet have always been acceptable as models. Both Laura and Beatrice were turned into characters by the poems they inspired. A poet as sensitive as Chaucer to this reification of the female allowed Criseyde to recognize and lament her own dilemma: "Allas, of me, unto the worldes ende, / Shall neyther ben ywriten nor ysonge / No good word; for these bokes wol me shende" (bk. 5, st. 152). Like the words written about her, she fears she will be "rolled on many a tongue!" Shakespeare also studied this entrapment of the woman: looking at Desdemona, whom he imagines dishonest, Othello asks, "Was this fair paper, this most goodly book, / Made to write 'whore' upon?" (4. 2. 71-72). ${ }^{8}$ The

\footnotetext{
${ }^{4}$ Hopkins, letter to Richard Watson Dixon, 30 June 1896, The Correspondence of Gerard Manley Hopkins and Richard Watson Dixon, ed. C. C. Abbott (London, 1935), p. 133. For a fuller discussion of the identification of paternity and creativity, see Sandra M. Gilbert and Gubar, The Madwoman in the Attic: The Woman Writer and the Nineteenth-Century Literary Imagination (New Haven, Conn., 1979), pp. 3-44.
}

${ }^{5}$ Margaret Atwood, untitled poem in the Circle/Mud sequence, You Are Happy (New York, 1974), p. 61.

${ }^{6}$ See Simone de Beauvoir, The Second Sex, trans. H. M. Parshley (New York, 1970).

${ }^{7}$ I am indebted for this view of Criseyde to Marcelle Thiebaux's "Foucault's Fantasia for Feminists: The Woman Reading" (paper delivered at the MMLA Convention, Indianapolis, 8 November 1979).

${ }^{8}$ The symbolic value of the "handkerchief / Spotted with strawberries" (3.3.434-45) is closely identified with Othello's fear that his "lust-stained" bedsheets must "with lust's blood be 
appropriation of the female "read" or "written" into textuality makes one wonder about many another heroine's fate. On more than one occasion, Dorothea Brooke in Middlemarch bemoans her inability to become a poet; how much of a comfort is Will Ladislaw's assurance to her that "You are a poem"?? Ezra Pound quotes a similar line to the poet H. D.: "You are a poem, though your poem's naught." 10 When the metaphors of literary creativity are filtered through a sexual lens, female sexuality is often identified with textuality.

We can see this clearly in Henry James' Portrait of a Lady, where the ideal jeune fille is described as "a sheet of blank paper." So "fair and smooth a page would be covered with an edifying text," we are told, whereas the experienced woman who is "written over in a variety of hands" has a "number of unmistakable blots" upon her surface. ${ }^{11}$ In To the Lighthouse, egotistical Mr. Ramsay sees his wife in a window "as an illustration, a confirmation of something on the printed page to which one returns, fortified and satisfied." 12 In Conrad's Victory, Axel Heyst saves a girl called Lena (after the seductress Magdalena) from "murdering silence" in an all-female orchestra by renaming her Alma (soul). Converted from artist to accompanist to accomplice, she seems "like a script in an unknown language" or "like any writing to an illiterate." Looking at her Heyst feels like a "man looking this way and that on a piece of writing which he was unable to decipher, but which may be big with some revelation." 13 From The Waste Land, in which a woman's hair "glow[s] into words," to The Great Gatsby, in which the "black rivulets" of mascara on a weeping woman lead to the "humorous suggestion ... that she sing the notes on her face," the female body has been feared for its power to articulate itself. ${ }^{14}$ More recently, Ishmael Reed describes sex in this way: "He got good into her Book tongued her every passage thumbing her leaf and rubbing his hands all over her binding." ${ }^{5}$ And John

spotted." For a brilliant discussion of male sexual anxiety in Othello, see Stephen J. Greenblatt, "Improvisation and Power," in Literature and Society: Selected Papers from the English Institute, ed. Edward W. Said (Baltimore, 1980), pp. 57-99.

${ }^{9}$ George Eliot, Middlemarch (Boston, 1968), p. 166.

${ }^{10}$ Pound, quoted by H. D., End To Torment (New York, 1979), p. 12.

${ }^{11}$ Henry James, The Portrait of a Lady (New York, 1978), pp. 238, 268. It is interesting to compare this view of the blank female text with the horror Margaret Laurence's heroine, Morag, feels at the dying, fat, and servile stepmother whose "face is as blank as a sheet of white paper upon which nothing will ever now be written" (The Diviners [Toronto, 1978], p. 250).

${ }^{12}$ Virginia Woolf, To the Lighthouse (New York, 1955), p. 53.

${ }^{13}$ Joseph Conrad, Victory (Garden City, N.Y, 1957), p. 183.

${ }^{14}$ T. S. Eliot, The Waste Land and Other Poems (New York, 1962), sec. 2, 1. 110; see also sec. 5, 11. 378-90: "A woman drew her long black hair out tight / And fiddled whispered music on those strings." F. Scott Fitzgerald, The Great Gatsby (New York, 1953), p. 34; see also p. 119 where Jordan Baker is described as "a good illustration."

${ }^{15}$ Ishmael Reed, Mumbo Jumbo (New York, 1978), p. 208-9. 
Berryman sums up the implications of this metaphor when he concludes a sequence of sonnets written to his mistress with the emphatic admission, "You are the text." 16

In fact contemporary critics not infrequently write about the act of reading in sexual terms. A "passage" of a text is a way of knowing a "corpus" or "body" of material that should lead us on, tease us-but not too obviously. "Knowing" a book is not unlike sexual knowing, as Roland Barthes has demonstrated in The Pleasure of the Text, his erotics of reading. ${ }^{17}$ Not only do we experience gratification orally as we "devour" books voraciously, we also respond subliminally to the "rhythms" of the plot, looking forward to a "climax." Furthermore, Claude Lévi-Strauss implies that the female must be identified with language used by men in the perpetuation of culture when he explains in Structural Anthropology that women are "circulated between clans, lineages, or families, in place of the words of the group, which are circulated between individuals."18 Similarly, William Gass argues that "ordinary language ought to be like the gray inaudible wife who services the great man: an ideal engine, utterly self-effacing, devoted without remainder to its task; but when language is used as an art it is no longer used merely to communicate. It demands to be treated as a thing, inert and voiceless." 19 The connection between women and words is less explicit but just as significant in David Lodge's Language of Fiction. Lodge asserts that the medium of fiction "is never virgin: words come to the writer already violated by other men...." 20 This corrupt lexicon presumably can be redeemed by the semantics of the text, for its seminal meaning is almost always closely associated with the seed or semen of the author's mind brooding on the repository of the page that bodies this meaning forth: Pound, for example, describes ideal creativity as a result of "the balance of the ejector [male] and

\footnotetext{
${ }^{16}$ John Berryman, Berryman's Sonnets (New York, 1967), p. 114. Russell Baker recently compared women to books, bemoaning the fact that "it is common nowadays to find yourself confronting a woman no thicker than a slim volume of poetry while buying a book wider than a piano" (“Sunday Observer," New York Times Magazine, 2 December 1979, p. 28).

${ }^{17}$ See Roland Barthes, The Pleasure of the Text, trans. Richard Miller (New York, 1975), p. 32: "There are those who want a text (an art, a painting) without a shadow, without the 'dominant ideology'; but this is to want a text without fecundity, without productivity, a sterile text (see the myth of the Woman without a Shadow)." Barthes' next book, A Lover's Discourse, makes the connection explicit by moving directly from the eroticism of texts to the eroticism of bodies.

${ }^{18}$ Claude Lévi-Strauss, Structural Anthropology, trans. Claire Jacobson and Brooke Grundfest Schoepf (New York, 1963), p. 61.

${ }^{19}$ William H. Gass, Fiction and the Figures of Life (New York, 1971), p. 93.

${ }^{20}$ David Lodge, Language of Fiction (New York, 1966), p. 47.
} 
retentive media [female]." ${ }^{21}$ And in an effort to criticize what he calls phallocentrism, Jacques Derrida describes the literary process in terms of the identification of the pen with the penis, the hymen with the page. As Gayatri Spivak explains in her introduction to Of Grammatology, "The hymen is the always folded ... space in which the pen writes its dissemination." ${ }^{22}$

This model of the pen-penis writing on the virgin page participates in a long tradition identifying the author as a male who is primary and the female as his passive creation-a secondary object lacking autonomy, endowed with often contradictory meaning but denied intentionality. Clearly this tradition excludes woman from the creation of culture, even as it reifies her as an artifact within culture. It is therefore particularly problematic for those women who want to appropriate the pen by becoming women writers. Especially in the nineteenthcentury, writers, who feared their attempts at the pen were presumptuous, castrating, or even monstrous, engaged in a variety of strategies to deal with their anxiety about authorship. Sandra M. Gilbert and I discuss some of these strategies in The Madwoman in the Attic. But just as important as the anxiety the male pen produces in the would-be woman writer is the horror she experiences at having been defined as his creation. Indeed, this problem seems to explain the coherence of nineteenth- and twentieth-century writing by women. Isak Dinesen's short story "The Blank Page" addresses this question with brilliant clarity. ${ }^{23}$ This story can be used to illustrate how woman's image of herself as text and artifact has affected her attitudes toward her physicality and how these attitudes in turn shape the metaphors through which she imagines her creativity.

Briefly, the story of "The Blank Page" centers on the sisters of a Carmelite order of nuns who grow flax to manufacture the most exquisite linen in Portugal. This linen is so fine that it is used for the bridal sheets of all the neighboring royal houses. After the wedding night, it is solemnly and publicly displayed to attest to the virginity of the princess and is then reclaimed by the convent where the central piece of the stained sheet "which bore witness to the honor of a royal bride" is mounted, framed, and hung in a long gallery with a plate identifying the

\footnotetext{
${ }^{21}$ Pound's postscript to his translation of Remy de Gourmont's Natural Philosophy of Love is discussed and quoted by Lawrence S. Dembo in Conceptions of Reality in Modern American Poetry (Berkeley, 1966), p. 158.

${ }^{22}$ Gayatri Chakravorty Spivak, introduction to Derrida, Of Grammatology (Baltimore, 1976), pp. lxv-lxvi. See also Derrida's discussion of how "woman is (her own) writing" in Spurs: Nietzsche's Style/Eperons: Les Styles de Nietzsche (Chicago, 1979), p. 57.

${ }^{23}$ Isak Dinesen, "The Blank Page," Last Tales (New York, 1957), pp. 99-105. Because of the frequent quotations and the brevity of the fable, I have omitted page numbers entirely. For useful criticism of this story, see Thomas R. Whissen, Isak Dinesen's Aesthetics (Port Washington, N.Y., 1973), pp. 101-6; Robert Langbaum, Isak Dinesen's Art: The Gayety of Vision (Chicago, 1975), p. 219; and Florence C. Lewis, "Isak Dinesen and Feminist Criticism," The North American Review 264 (Spring 1979): 62-72.
} 
name of the princess. These "faded markings" on the sheets are of special interest to female pilgrims who journey to the remote country convent, for "each separate canvas with its coroneted name-plate has a story to tell, and each has been set up in loyalty to the story." But pilgrims and sisters alike are especially fascinated by the framed canvas over the one nameless plate which displays the blank, snowwhite sheet that gives the story its title.

Before approaching the mysterious promise of this blank page, let us consider the framed, bloodied sheets in the convent gallery, which is both a museum of women's paintings (each sheet displays a unique, abstract design and is mounted in a heavy frame) and a library of women's literary works (the bloodstains are the ink on these woven sheets of paper). Collected and cherished by a female community that has seen better days, a kind of paradigmatic women's studies department, these bloodstained marks illustrate at least two points about female anatomy and creativity: first, many women experience their own bodies as the only available medium for their art, with the result that the distance between the woman artist and her art is often radically diminished; second, one of the primary and most resonant metaphors provided by the female body is blood, and cultural forms of creativity are often experienced as a painful wounding. Although I will deal with each point separately, they are clearly related, for the woman artist who experiences herself as killed into art may also experience herself as bleeding into print.

As to my first point, the objects of art in "The Blank Page" are quite literally made out of the bodies of the royal princesses whose internal fluids are the print and the paint. Not only are artist and art object physically linked but also the canvases in the nuns' gallery are a direct response to the princesses' private lives. Royal ladies and highborn spinsters would proceed "on a pilgrimage which was by nature both sacred and secretly gay" to read the canvas bearing the name of a princess they had once served and to review the bride's life as a wife and mother. The stained pages are therefore biographical remnants of otherwise mute existences, a result of and response to life rather than an effort at producing an independent aesthetic object. Indeed, were the female community less sensitive to the significance of these signs, such stained sheets would hardly be considered art at all. Dinesen implies that woman's use of her own body in the creation of art results in forms of expression devalued or totally invisible to eyes trained by traditional aesthetic standards. She also seems to imply that, within the life of domesticity assigned the royal princess from birth, the body is the only accessible medium for self-expression.

Certainly women's limited options-expressed in the parable by the fact that all royal (privileged) women marry while all single women are nuns-have shaped the art they create. Unable to train themselves as painters, unable to obtain the space or income to become sculptors, gifted women in these areas have had to work in private, using the only materials at hand-their bodies, their 
selves. If, as Dinesen implies, female creativity has had to express itself within the confines of domesticity (in part because of the emphasis on the personal in female socialization), women could at the least paint their own faces, shape their own bodies, and modulate their own vocal tones to become the glass of fashion and the mold of form. To make up, for such women, means not only making up stories but making up faces. In terms of the Pygmalion myth with which I began, the woman who cannot become an artist can nevertheless turn herself into an artistic object.

Nowhere is this better illustrated than in the novels of George Eliot, in which many female characters squander their creativity on efforts to reconstruct their own images. From Hetty Sorrel in Adam Bede (1859), who peers at her earrings and ribbons in a blotched mirror as she sits at a dressing table where the brass handles hurt her knees, to Gwendolen Harleth in Daniel Deronda (1876), who poses as Saint Cecilia in a glass exquisitely framed in black and gold, Eliot analyzes the ways in which women's creativity has been deformed by being channeled into self-destructive narcissism. Eliot criticizes the idea that beauty is an index of moral integrity by demonstrating how narcissism infantilizes the female, turning her from an autonomous person into a character in search of an author (or a page in search of a pen, to keep up the metaphor with which I began). Such a woman is always and only "becoming"-that is, she is beautiful but she is also always imagining some future identity that she is unable to realize by herself.

Hetty, for example, is like a hopeful child waiting to be adopted and adapted by Arthur Donnithorne. Gwendolen's case is even clearer. After arranging at a party a series of tableaux vivants to gain the admiration of prospective suitors, she chooses to represent herself imitating a character who looks like a statue. Instead of turning back to life on cue, Gwendolen is terrified by a picture of a dead face that unexpectedly springs out of a movable panel before her eyes; when she returns to herself, she looks "like a statue into which a soul of Fear had entered: her pallid lips were parted; her eyes, usually narrowed under their long lashes, were dilated and fixed." ${ }^{4}$ The dead face, Eliot implies, is Gwendolen's own. For in the process of turning herself into an artistic object, she makes herself autistic. Increasingly enmeshed in dreadful hallucinatory visions of her own distress, Gwendolen eventually is impelled to desire the death of her husband and her own death. Eliot's conviction that female creativity has been perverted (here as female narcissism and elsewhere in Eliot's fiction as enthrallment to male authority) helps us understand why she never wrote a Kunstlerroman.

\footnotetext{
${ }^{24}$ Eliot, Daniel Deronda (Baltimore, 1967), p. 91.
} 
Many female modernists have studied the deflection of female creativity from the production of art to the re-creation of the body, ${ }^{25}$ but Edith Wharton, especially in The House of Mirth (1905), was most clearly influenced by Eliot. Cynthia Griffin Wolff has already brilliantly shown how Wharton's first title, "A Moment's Ornament," captures "the decorative imperative of that aspect of femininity that Lily embodies and the ultimate fragility of a self that has grown out of that imperative." ${ }^{26}$ Lily Bart's gracefulness, her stylish clothing, her belief in the power of her own beauty to do good, her use of furniture and nature as backdrop scenery, even the lines on her face she traces with dismay in the mirror justify Diana Trilling's view that "Lily herself possesses the quality of a fine work of art." ${ }^{27}$ Because financially she cannot afford to maintain herself as a work of art without the money of a man, Lily's artful presentation resembles Gwendolen's; she too must attract a husband. Furthermore, the only man in the novel who could possibly save her from becoming a commodity on the marriage market is himself incapable of viewing her as anything but a collectable in the aesthetic market: "As a spectator, Lawrence Selden had always enjoyed Lily Bart," making "use of the "argument from design," for he knows that "she must have cost a great deal to make" (p. 3). In fact, he believes that "even her weeping was an art" (p. 69). While he is correct that her self-presentation empties her of spontaneity and makes her relationships duplicitous, Selden only further imprisons her in this ornamental behavior by characterizing it as so uniquely her own.

Although Lily's art does not procure her security in the form of a husband, and although she is quite destitute on her deathbed at thirty years of age, Lily seems to triumph at the end of The House of Mirth, for her death is the logical extension of her life. Having turned herself into an artistic object, she now literally kills herself into art. Significantly, before taking the overdose that lulls her to sleep and death, Lily goes through her wardrobe of dresses which "still

\footnotetext{
${ }^{25}$ Elinor Wylie (herself a beautiful woman) wrote a series of poems and novels about the "firing" of girls into porcelain artifacts. For a fuller discussion of Wylie's attraction to formal perfection, see Célèste Turner Wright, "Elinor Wylie: The Glass Chimaera and the Minotaur," Women's Studies 7, nos. 1 and 2 (1980): 159-70 (special issue on women poets, ed. Gilbert and Gubar).

${ }^{26}$ Cynthia Griffin Wolff, A Feast of Words: The Triumph of Edith Wharton (New York and Oxford, 1977), p. 109; all further references to Wharton's The House of Mirth, ed. R. W. B. Lewis (New York, 1977), will be included in the text. Wharton's second provisional title, "The Year of the Rose," points up the ways in which the Jew Rosedale is a double for Lily, in part because his Semitism allows him to glimpse the sordid economic realities behind the veneer of culture, much as Wharton's feminism did for her. For a useful consideration of Wharton's debt to Eliot, see Constance Rooke, "Beauty in Distress: Daniel Deronda and The House of Mirth," Women and Literature 4, no. 2 (Fall 1976): 28-39.

27 Diana Trilling, "The House of Mirth Revisited," in Edith Wharton, ed. Irving Howe (Englewood Cliffs, N.J., 1962), p. 109.
} 
kept the long unerring lines, the sweep and amplitude of the great artist's stroke, and as she spread them out on the bed the scenes in which they had been worn rose vividly before her" (p. 211). She remembers specifically the party at which she, like Gwendolen, participated in tableaux vivants; when Lily turned herself into Reynolds' portrait of "Mrs. Lloyd," she looked "as though she had stepped, not out of, but into, Reynolds' canvas" (p. 131), thereby demonstrating to Selden and the other onlookers "the touch of poetry in her beauty" (p. 131).

While Lily waits in bed for the drug to bring oblivion, she thinks that there is "some word she had found" to tell Selden that would make everything well ( $\mathrm{p}$. 317). On entering her room, Selden sees "a narrow bed along the wall, and on the bed, with motionless hands and calm, unrecognizing face, the semblance of Lily Bart." He kneels by this semblance for a final moment, "drain[ing] their last moment to the lees; and in the silence there passed between them the word which made all clear" (p. 323). This word is Lily's dead body; for she is now converted completely into a script for his edification, a text not unlike the letters and checks she has left behind to vindicate her life. She submits to being thus defined, although she liberates her lover from such a degradation by destroying his letters. Lily's history, then, illustrates the terrors not of the word made flesh but of the flesh made word. In this respect, she illuminates the problems Wharton must have faced in her own efforts to create rather than be createdefforts not always successful, if we can trust the reported comments of as important a contemporary critic as Percy Lubbock who, in comparing her to Henry James, quipped: "She was herself a novel of his, no doubt in his earliest manner." 28

Like Kafka's victim in "The Penal Colony," women have had to experience cultural scripts in their lives by suffering them in their bodies. This is why Maxine Hong Kingston writes so movingly about her resemblance to the mythic woman warrior who went into battle scarred by the thin blades which her parents literally used to write fine lines of script on her body. ${ }^{29}$ For the artist, this sense that she is herself the text means that there is little distance between her life and her art. The attraction of women writers to personal forms of expression like letters, autobiographies, confessional poetry, diaries, and journals points up the effect of a life experienced as an art or an art experienced as a kind of life, as does women's traditional interest in cosmetics, fashion, and interior decorating. Many books by women writers (like Dorothy Richardson's Pilgrimage and Olive Schreiner's From Man to Man) cannot be finished because they are as ongoing and open-ended as the lives of their authors. The mythic lives of women artists

\footnotetext{
${ }^{28}$ Lubbock, quoted in Millicent Bell, Edith Wharton and Henry James: The Story of Their Friendship (New York, 1965), p. 21.

${ }^{29}$ See Maxine Hong Kingston, The Woman Warrior: Memoirs of a Girlhood among Ghosts (New York, 1977), pp. 41-42 and 62-63.
} 
from Emily Dickinson (who played out the Gothic fiction of the white-dressed maiden imprisoned in daddy's house) to Isadora Duncan (whose costumes and affairs and death express her creed as well as her autobiography does) also reveal the close identification experienced between the female artist and her art. Duncan's medium, dance, has always been acceptable for women, I suspect, because the body of the dancer becomes an instrument or icon on stage.

Not a few of the most exciting experiments of women artists, moreover, grow out of a self-conscious attempt to obliterate aesthetic distance. The insistence that the domestic is artistic is illustrated, for example, by Katherine Mansfield, who writes lovingly about the ways in which a kitchen is decorated with utensils and food. ${ }^{30}$ It finds a kind of culmination in the performative art of Mierle Laderman Ukeles, whose "Maintenance Art Activity" consists in washing museum floors with a damp mop, over and over again, and even more to the purpose here, Carolee Schneemann, who reads from a long scroll she removes from her vagina in her performance of Up To and Including Her Limits (1975). ${ }^{31}$ Writing about Eleanor Antin's videotape in which she applies makeup to the "canvas" of her face and her photo sequence in which she documents "carving" ten pounds off her body, Arlene Raven and Deborah Marrow explain that "Antin's work is of the verb rather than the object" in its effort to illuminate how "in this culture women themselves are the art product." 32 Judy Chicago's The Dinner Party celebrates creative women who, refusing conventional definitions of the female, are in a privileged position to question the definitions of art that our culture accepts. ${ }^{33}$ But The Dinner Party plates also imply that women, who have served, have been served up and consumed. They therefore remind us of the sacrificial nature of the body "dressed" as art. Indeed, in The House of Mirth the fashion plate often lifts a face "like an empty plate held up to be filled" (p. 45); Lily's beauty is described as a "glaze," (pp. 3 and 51), reminding us of the fragility and vulnerability of Chicago's "service."

The stain that darkens the reputation of a girl like Lily and the stains of vaginal imagery at the center of the porcelain plates turn us to my second point,

\footnotetext{
${ }^{30}$ Domestic artistry is repeatedly celebrated in Mansfield's stories, most especially in the figure of Mrs. Fairfield in "Prelude" (The Short Stories of Katherine Mansfield, ed. John Middleton Murry [New York, 1976]), but also throughout the letters in which Mansfield writes about the culinary skills of a maid or the interior decorating she herself performs on a hotel room.

${ }^{31}$ For a photograph of Mierle Laderman Ukeles performing her Washing, Tracks, Maintenance: Maintenance Art Activity III (22 July 1973), see Lucy R. Lippard, From the Center: Feminist Essays on Women's Art (New York, 1976), p. 60; for her discussion of Carolee Schneemann, see p. 126.

32 Arlene Raven and Deborah Marrow, "Eleanor Antin: What's Your Story," Chrysalis 8 (Summer 1979): 43-51.

${ }^{33}$ See Judy Chicago, Through the Flower: My Struggle as a Woman Artist (New York, 1975) and her book on the work, The Dinner Party (Garden City, N.Y., 1979).
} 
the centrality of blood as a symbol furnished by the female body. Luce Irigaray has argued recently that women are made vulnerable by their inability to express their delirium: "Women do not manage to articulate their madness: they suffer it directly in their body." 34 In "The Blank Page," the sacrificial suffering of the inarticulate female body is revealed in the bloody ink print, which is the result of the hymen's penetration and which is so valued by the community; the high steward to the royal house proclaims, "Virginem eam tenemus-'we declare her to have been a virgin." While bloodstains can be a certification of freedom from pregnancy or the mark of entrance into puberty, in the Dinesen story they call to mind the more tragic associations of blood for women, especially for women writers. Unlike the blood of menstruation which presumably defiles like a curse or the blood of childbirth which is also taboo, the blood on the royal sheets is holy, for it certifies purity. By making the sheets into objects as sacred as altar cloths, the nuns sanctify the sacrifice of the virgin, and by reading the stains as if they were hieroglyphs, they imply that we must come to terms with the fact of blood before we can understand the nature of female art.

Lest this seem too gothic a pronouncement, let me point to as pious and proper a poet as Christina Rossetti, for this Victorian conspicuously offers her song as a virginal blood sacrifice. ${ }^{35}$ At least part of Rossetti's plan came from her sense that she was the model, not the painter, the character, not the author. She has been represented, moreover, "Not as she is, but as she fills his dream" ("In an Artist's Study"). Rossetti therefore experiences herself as "Dead before Death," to quote the title of a characteristic poem. In "From the Antique" she is explicit about her life's being "Doubly blank in a woman's lot." As in Dinesen's tale of the convent, Rossetti's speaker on the doorstep of "The Convent Threshold" feels caught between sexuality and chastity. Choosing to become a nun because there is mysterious "blood" between her lover and herself, she looks down to see her lily feet "soiled with mud, / With scarlet mud which tells a tale" [my italics]. The same identification of bleeding with telling or singing appears in the vision of the suffering woman poet in "From House to Home." Beginning with a sense of sinfulness, of being stained, Rossetti transforms herself in a number of religious poems into the bride of Christ and into a female Christ (she had modelled for a painting of the Virgin Mary). Imitating his blood sacrifice, she testifies repeatedly to the "mark of blood" that distinguishes her door ("Despised and Rejected"). But this sign also recalls the tokens of virginity on the cloth brought before the elders of the city to redeem the honor of a slandered bride, as described and prescribed in Deuteronomy. ${ }^{36}$

\footnotetext{
${ }^{34}$ Irigaray, quoted by Diana Adlam and Couze Venn in "Women's Exile: Interview with Luce Irigaray," Ideology and Consciousness (Summer 1978): 74.

${ }^{35}$ See The Complete Poems of Christina Rossetti, ed. R. W. Crump (Baton Rouge, La., 1979).

${ }^{36}$ See Deut. 22:13-24. I am indebted to Stephen Booth for pointing out the relevance of this biblical passage. The issue of blood and sacrifice is a complicated one in the Catholic tradition,
} 
The blood sacrifice of the royal princesses in Dinesen's story represents the sacrifice of virginity not through martyrdom but through marriage, although the stained sheets also seem to imply that marriage may be a martyrdom. The blood on the royal sheets is considered holy because it proves that the bride is a valuable property, given by father to husband for the production of sons. In other words, before the sheet is collected by the convent sisters and assumes the status of art, the bloodstains are a testimony to the woman's function as a silent token of exchange. But this blood wedding transforms the marriage bed into a kind of coffin in which the virgin is sacrificed. Dinesen may have considered her own marriage deathly because she believed her many illnesses in later life were related to the syphilis she unwittingly contracted from her husband, but she implies that many women in a patriarchy experience a dread of heterosexuality. The storyteller of "The Blank Page," who has told "one more than a thousand" tales, is thereby associated with Scheherazade, who told stories in the night to circumvent the death awaiting her after sexual initiation in the bridal chamber. ${ }^{37}$ Not only a surrogate for her own body, her stories save the daughters of the land who have been threatened with penetration and execution by the misogynist king who is enraged by the infidelity of women.

The framed stained sheets imply, then, that all the royal princesses have been "framed" into telling the same story, namely, the story of their acquiescence as objects of exchange. The American poet H. D. treats this confinement as a primary plot (conspiracy) against women and an effective plot (burial mound) for women. ${ }^{38}$ She has therefore dedicated her late poems to excavating the female by creating alternative scripts, as she explains in Trilogy (1944-46), where her muse carries "the blank pages / of the unwritten volume of the new." 39 In Helen in Egypt (1961), H. D. begins with a character who is a phantom because she has

as this quotation from Charles Williams illustrates: "There is also, of course, that other great natural bloodshed common to half the human race-menstruation. That was unclean. But it is not impossible that that is an image, naturally, of the great bloodshed on Calvary, and perhaps, supernaturally, in relation to it. Women share the victimization of the blood; it is why, being the sacrifice so, they cannot be the priests. They are mothers, and, in that special sense, victims; witnesses, in the body, to the suffering of the body, and the method of Redemption" (The Forgiveness of Sins [London, 1950], p. 138).

${ }^{37}$ Scheherazade is an important model of the female storyteller for Dinesen. See the conclusion of "The Deluge at Norderney," Seven Gothic Tales (New York, 1972), p. 79, and Hannah Arendt's foreword, "Isak Dinesen, 1885-1962," to Dinesen's Daguerreotypes (Chicago, 1979), p. xiv. See also Gilbert's poem “Scheherazade," Poetry Northwest 19, no. 2 (Summer 1978): 43.

${ }^{38}$ On women's entrapment in erotic plots, see Elizabeth Hardwick, Seduction and Betrayal: Women and Literature (New York, 1974), pp. 175-208, and Joanna Russ, "What Can a Heroine Do; or, Why Women Can't Write," in Images of Women in Fiction: Feminist Perspectives, ed. Susan Koppelman Cornillon (Bowling Green, Ohio, 1972), pp. 3-20.

${ }^{39}$ H. D., Trilogy (New York, 1973), p. 103. 
barely survived being turned into a heroine. Basing her epic on a seventh-century palinode by Stesichorus that claims Helen never got any further than Egypt-it was merely an image of Helen that accompanied Paris to Troy to give the pretext for war-H. D. shows us a Helen haunted by stories told about the war, specifically, the blame heaped on her for presumably causing it and the role allotted to her as an object of exchange: war booty, gift, ransom. ${ }^{40}$ Helen realizes at the beginning of H. D.'s revisionary epic that her own imagined role in the war was a sacrifice inflicted on her, that "the script was a snare" (p. 220). But it is terribly difficult for her to evade this snare or escape it, because, like Eliot's and Wharton's heroines and Dinesen's royal princesses, she feels that "She herself is the writing" (p. 91). She tries to rescue herself by considering other stories of growing up female, but these turn out to be the same story of the blood sacrifice of daughters and virgins: Iphigenia, Polyxena, Chryseis, Cassandra, and Persephone.

"Helen returns constantly to this theme of sacrifice" (p. 84) because the daughters "were all sacrificed in one way or another" (p. 173). Inside this blood factory, she mourns the "bridal pledge at the altar" as a "pledge to Death" (p. 73). Her blood consciousness harkens back to the mythic female artist, Philomela: raped by Tereus who cut out her tongue, Philomela took her revenge by weaving her story for all to see with "purple / On a white background." 41 In addition, Helen's blood consciousness also reaches forward to contemporary poems (by writers like May Swensen and Marge Piercy) in which the phallus is a weapon. The desecrated female body that feels like the self of the poet bleeds into print. ${ }^{42}$ Anne Sexton therefore associates her female anatomy with the absence of control: in her female revision of The Waste Land, "Hurry Up Please It's Time," she identifies herself with Eliot's wasted, working-class women, for she knows "I have ink but no pen." As a result, Sexton feels that her poems "leak" from her "like a miscarriage." ${ }^{43}$ Likewise, Frida Kahlo, who presents herself as bound by red cords that are not only her veins and her roots but also her paint, is a painter

\footnotetext{
${ }^{40}$ H. D., Helen in Egypt (New York, 1961); all further references to this poem will be included in the text.

${ }^{41}$ Ovid, Metamorphoses, trans. Humphries, pp. 148-51. Significantly, once Procne reads Philomela's story, she kills her own son and cooks him up for Tereus who is made to eat him. The sisters are transformed into birds, "And even so the red marks of the murder / Stayed on their breasts; the feathers were blood-colored."

${ }^{42}$ See May Swenson, "Cut," Iconographs (New York, 1970), p. 13, and Marge Piercy, "I Still Feel You," in Psyche: The Feminine Poetic Consciousness, ed. Barbara Segnitz and Carol Rainey (New York, 1973), pp. 187-88.

${ }^{43}$ Anne Sexton, "Hurry Up Please It's Time," The Death Notebooks (Boston, 1974), p. 62; "The Silence," Book of Folly (Boston, 1972), p. 32.
} 
whose tragic physical problems contributed to her feeling wounded, pierced and bleeding. ${ }^{44}$

Mired in stories of our own destruction, stories which we confuse with ourselves, how can women experience creativity? In Dinesen's story, the creation of female art feels like the destruction of the female body. Because of the forms of self-expression available to women, artistic creation often feels like a violation, a belated reaction to male penetration rather than a possessing and controlling. Not an ejaculation of pleasure but a reaction to rending, the blood on the royal marriage sheets seems to imply that women's paint and ink are produced through a painful wounding, a literal influence of male authority. If artistic creativity is likened to biological creativity, the terror of inspiration for women is experienced quite literally as the terror of being entered, deflowered, possessed, taken, had, broken, ravished-all words which illustrate the pain of the passive self whose boundaries are being violated. In fact, like their nineteenth-century foremothers, twentieth-century women often describe the emergence of their talent as an infusion from a male master rather than inspiration from or sexual commerce with a female muse. This phallic master causes the woman writer to feel her words are being expressed from her rather than by her. Like Mary Elizabeth Coleridge who sees her lips as a silent wound, or Charlotte Bronte who suffers from a "secret, inward wound" at the moment she feels the "pulse of Ambition," or Emily Dickinson who is bandaged as the empress of Calvary in some poems and as the wounded deer in others, women writers often dread the emergence of their own talents. ${ }^{45}$

If writing feels as if "the ink was pouring on to the sheets like blood," as it does for the heroine of Margaret Drabble's The Waterfall, then the poet can easily become frightened by her sense of victimization: "I was unnaturally aware of my own helpless subjugation to my gifts, my total inability to make a poem at will," Drabble's poet explains. "I resented this helplessness as I resented a woman's helplessness with a man." ${ }^{46}$ The twentieth-century prototype of this anxious sense that poetry comes from being possessed and wounded is, of course, Sylvia Plath. Like Drabble's heroine, whose creativity is released by giving birth to a second child, Plath begins Ariel with a relatively cheerful poem about childbirth that seems to promise a more positive way of imagining creativity for women. But even here in "Morning Song," the new birth of morning seems converted into grief and mourning, for the child is a "New statue" and the

\footnotetext{
${ }^{44}$ See Joyce Kozloff, “Frida Kahlo,” Women's Studies 7 (1978): 43-58.

${ }^{45}$ See Mary Elizabeth Coleridge, "The Other Side of a Mirror," The World Split Open: Four Centuries of Women Poets in England and America, 1552-1950, ed. Louise Bernikow (New York, 1974), p. 137; Charlotte Brontë, The Professor (New York, 1964), p. 195; and the discussion of Emily Dickinson in Gilbert and Gubar, The Madwoman in the Attic, pp. 581-650.

${ }^{46}$ Margaret Drabble, The Waterfall (New York, 1977), pp. 114-15.
} 
parents "stand round blankly as walls." This statue, confined by blank walls, is transformed into the far more terrible wife of "The Applicant": "Naked as paper to start," she is "A living doll." Like Pygmalion's ivory girl, Atwood's mud woman, Eliot's living statues, Lily Bart who really is a living doll, or Sexton who is her own dead doll, Plath's wife is a kind of automaton in the clutches of someone else's will. Plath herself is not infrequently filled with a "thin / Papery feeling" which helps explain the thousands of paper dolls she played with as a child, and her poems lend sinister insight into Mansfield's perception that "Female dolls in their nakedness are the most female things on earth." ${ }^{47}$ From Maggie Tulliver, who tortures her doll in the attic in The Mill on the Floss, to Pecola Breedlove in Toni Morrison's The Bluest Eye, who tortures herself because she cannot look like her doll, the heroines of women's fiction have played with dolls to define themselves.

Plath can only escape the dread that she has been created as an object (as she says in "Lady Lazarus," "I am your opus") by self-inflicted violence, by watching the bloodstain darkening the bandages, proving she is alive. A sense of helplessness seems inextricably related to the emergence of her voice: "By the roots of my hair some god got hold of me," Plath exclaims in "The Hanging Man"; "I sizzled in his blue volts like a desert prophet." As terrible as her muse is, however, her pain at his violation also proves she is alive. But the jolting words snapped out by these electric charges mean that the poetry Plath creates will kill her: "The blood jet is poetry, / There is no stopping it" ("Kindness"). She has had the blood sucked out of her by "Daddy," who "Bit [her] pretty red heart in two." While she has killed "The vampire who said he was you/ And drank my blood for a year," she is still haunted by the black bat airs, and, having been bitten, she has herself become a bloodsucker, for "The blood flood is the flood of love" ("The Munich Mannequins"). The redness of the "Tulips" in her hospital bed therefore "talks to [her]wound, it corresponds." If she sees herself as "flat, ridiculous, a cutpaper shadow / Between the eye of the sun and the eyes of the tulips," she knows she will eventually fly into these eyes which are, of course, "the red / Eye, the cauldron of morning" ("Ariel”). The only way to escape papery perfection in "Stings" is to become the "red / Scar in the sky." At the end of Ariel, she is finally perfected into a statue: "The illusion of a Greek necessity / Flows in the scrolls of her toga" as she accepts her role as heroine in the tragedy that is not only her art but her life ("Edge"). The dialectic between perfection and blood destruction means finally that Plath's "Words" are "Axes" from whose rhythmic strokes she will never recover. ${ }^{48}$

\footnotetext{
${ }^{47}$ Katherine Mansfield to Violet Schiff, October 1921, Letters, ed. Murry (New York, 1932), pp. 405-6. It is significant in this regard that both Mansfield and H. D. can only imagine the reeducation and redemption of boys in terms of their learning to play with dolls.

${ }^{48}$ See Sylvia Plath, Ariel (New York, 1965). Plath's paper doll collection can be seen in the Lilly Library at Indiana University.
} 
Adrienne Rich also identifies blood with the female body: "Sometimes every / aperture of my body / leaks blood. I don't know whether / to pretend that this is natural." In other words, Rich is aware that even her most intimate attitudes toward her own blood have been defined by male voices:
You worship the blood
you call it hysterical bleeding
you want to drink it like milk
you dip your finger into it and write
you faint at the smell of it
you dream of dumping me into the sea. ${ }^{49}$

Rich seeks a way of experiencing the blood through her own sensibilities. In "Women," she sees three Fates who seem to represent her sense of women's progress in history: the first sister is sewing a costume for her role as Transparent Lady when "all her nerves will be visible"; the second is sewing "at the seam over her heart which has never healed entirely"; and the third is gazing "at a dark-red crust spreading westward far out on the sea." 50 Her beauty and her vision promise a time when women can authentically deny that our "wounds come from the same source as [our] power." ${ }^{1}$ Refusing a poetry that implies performance, competition, or virtuosity, Rich strives in her most recent volume for "the musings of a mind / one with her body," within

... the many-lived, unending

forms in which she finds herself,

becoming now the sherd of broken glass

slicing light in a corner, dangerous

to flesh, now the plentiful, soft leaf

that wrapped round the throbbing finger, soothes the wound. ${ }^{52}$

Rich's promise returns us to Dinesen's story, for the snow-white sheet of the nameless princess also seems to promise a breakthrough into new beginnings for new stories that can soothe the wound. The single and singular blank sheet that

\footnotetext{
49 Adrienne Rich, "Waking in the Dark," Adrienne Rich's Poetry, ed. Barbara Charlesworth Gelpi and Alpert Gelpi (New York, 1975), p. 61.

${ }^{50}$ Rich, "Women," in Psyche, ed. Segnitz and Rainey, p. 152.

${ }^{51}$ Rich, "Power," The Dream of a Common Language (New York, 1978), p. 3.

${ }^{52}$ Rich, “Transcendental Etude,” ibid., p. 77.
} 
so fascinates pilgrims and nuns alike in the convent library-museum seems an alternative to the bloody sheets that surround it. Thus, in terms of the patriarchal identification of women with blankness and passivity with which we began, Dinesen's blank page becomes radically subversive, the result of one woman's defiance which must have cost either her life or her honor. Not a sign of innocence or purity or passivity, this blank page is a mysterious but potent act of resistance. The showing of the sheet, moreover, proves that the anonymous princess has forced some sort of acknowledgment or accommodation in the public realm. On a literal level, the blank sheet may mean any number of alternative scripts for women: Was this anonymous royal princess not a virgin on her wedding night? Did she, perhaps, run away from the marriage bed and thereby retain her virginity intact? Did she, like Scheherazade, spend her time in bed telling stories so as to escape the fate of her predecessors? Or again, maybe the snow- white sheet above the nameless plate tells the story of a young woman who met up with an impotent husband, or of a woman who learned other erotic arts, or of a woman who consecrated herself to the nun's vow of chastity but within marriage. Indeed, the interpretation of this sheet seems as impenetrable as the anonymous princess herself. Yet Dinesen's old storyteller, who learned her art from her grandmother much as her grandmother learned it from her own mother's mother, advises her audience to "look at this page, and recognize the wisdom of my grandmother and of all storytelling women!"

The storyteller says this, I think, first of all because the blank page contains all stories in no story, just as silence contains all potential sound and white contains all color. Tillie Olsen's Silences and Rich's On Lies, Secrets, and Silences teach us about the centrality of silence in women's culture, specifically the ways in which women's voices have gone unheard. While male writers like Mallarmé and Melville also explored their creative dilemmas through the trope of the blank page, female authors exploit it to expose how woman has been defined symbolically in the patriarchy as a tabula rasa, a lack, a negation, an absence. But blankness here is an act of defiance, a dangerous and risky refusal to certify purity. The resistance of the princess allows for self-expression, for she makes her statement by not writing what she is expected to write. Not to be written on is, in other words, the condition of new sorts of writing for women. The nuns and the storyteller recognize wisdom in the place where the uninitiated see nothing, in part by removing their attention from the traditional foreground to what is usually relegated to background, much as we might radically revise our understanding of the 1,001 blank days during which Scheherazade silently bore the king three sons whose surprise appearance at the end of the 1,001 nights wins her a reprieve from the death sentence. But the old crone also praises the blank sheet because it is the "material" out of which "art" is produced. Women's creativity, in other words, is prior to literacy: the sisterhood produces the blank sheets needed to accomplish writing. 
Olive Schreiner, the great feminist theorist, explains what this implies about English culture when one of her heroines holds up a book and theorizes about literary history:

When I hold these paper leaves between my fingers, far off across the countless ages I hear the sound of women beating out the fibres of hemp and flax to shape the first garment, and, above the roar of the wheels and spinnies in the factory, I hear the whirr of the world's first spinning wheel and the voice of the woman singing to herself as she sits beside it, and know that without the labor of those first women kneeling over the fibres and beating them swiftly out, and without the hum of those early spinning wheels, neither factory nor paper pulp would ever have come into existence....This little book! - it has got its roots down, down, deep in the life of man on earth; it grows from there. ${ }^{53}$

If we take Schreiner's claim seriously, no woman is a blank page: every woman is author of the page and author of the page's author. The art of producing essentials-children, food, cloth-is woman's ultimate creativity. If it is taken as absence in the context of patriarchal culture, it is celebrated within the female community by the matrilineal traditions of oral storytelling. The veiled, brown, illiterate old woman who sits outside the city gates in Dinesen's tale therefore represents her grandmother and her grandmother's grandmother: "they and I have become one." Existing before man-made books, their stories let us "hear the voice of silence."

The blank page is created in Dinesen's story through the silent act of "sowing" the flax seed and "sewing" the linen, acts traditionally performed by the female community. This is the subversive voice of silence, and we can associate it with the silent sound of Philomela's shuttle. The process whereby "the seed is skillfully sown out by labor-hardened virginal hands" and the "delicate thread is spun, and the linen woven" is the secret of Dinesen's society of convent spinsters. For the nuns who have raised the production of flax into art, then, the blank page is a tribute to what has been devalued as mere craft or service. The nuns refuse to relegate the domestic or the decorative to a category outside the realm of true creativity. At the same time, moreover, they sanctify their own creative efforts; for the germ of the story, the first seed of the flax, comes from the holy land of the daughter Achsah who sought and received a blessing-specifically, the blessing of springs of water. When the flax blooms, we are told, the valley becomes "the very color of the apron which the blessed virgin put on to go out and collect eggs within St. Anne's poultry yard, the moment before the Archangel Gabriel in mighty wing-strokes lowered himself onto the threshold of the house,

${ }^{53}$ Olive Schreiner, From Man to Man (Chicago, 1977), p. 409. 
and while high, high up a dove, neck-feathers raised and wings vibrating, stood like a small clear silver star in the sky."

Members of this "blithe sisterhood" thus preserve the history of lesser lives in the blood markings and glorify the blank page as a sacred space consecrated to female creativity, thereby pulling heaven down to earth. While the bloodstained sheets resemble the true icon of suffering divinity as seen on Veronica's veil, the virgin-blue flax blossoms remind us of Mary at the moment before the Annunciation-Mary waiting, about to become pregnant with divinity. ${ }^{54}$ In her readiness for rapture, she represents the female community, and its blank page is therefore hers. The convent in Dinesen's story is a Carmelite order, the order which propagates a special devotion to our Lady; indeed, in the Middle Ages, Carmelite theologians were among the earliest defenders of the Immaculate Conception, the doctrine that Mary was conceived without original sin. But the Carmelites have also produced the greatest Christian mystics, most importantly Saint Theresa, who inspired Dorothea Brooke's, and George Eliot's, quest for a life of significant action. Like Mary, whose sanctity is hidden in the ordinary, Theresa's mysticism was grounded in the everyday. The vows of poverty, chastity, and obedience taken by the Carmelite nuns are strenuous attempts to aid contemplation, to achieve Theresa's ordinary mysticism. Not martyrs who suffer death but prophets who suffer inspiration, the convent virgins spend much time in silence, seeking to duplicate Mary's receptivity to bearing and giving birth to the Incarnate Word. ${ }^{55}$ Thus, the blank place, a female inner space, represents readiness for inspiration and creation, the self conceived and dedicated to its own potential divinity.

Many of the late-Victorian and twentieth-century women writers whom I have mentioned were involved in the creation of a revisionary theology that allowed them to reappropriate and valorize metaphors of uniquely female creativity and primacy. I have space here only for a few examples. Florence Nightingale in Cassandra (1852), pronounced her audacious belief that "the next Christ will perhaps be a female Christ." ${ }^{56}$ Schreiner claimed by extension that

\footnotetext{
${ }^{54}$ I am indebted to Mary Jo Weaver for informing me that the image on Veronica's headcloth has been associated by the gnostics with the woman cursed by blood in Matt. 9:20-22.

${ }^{55}$ See Thomas Merton, Disputed Questions (New York, 1960), pp. 222 and 227. For a feminist discussion of the usefulness of the figure of the Virgin Mary to Catholic women, see Elisabeth Schussler Fiorenza, "Feminist Spirituality, Christian Identity, and Catholic Vision," in Womanspirit Rising, ed. Christ and Plaskow, pp. 138-39, and Drid Williams, "The Brides of Christ," in Perceiving Women, ed. Shirley Ardener (London, 1975), pp.105-26. The most important feminist analysis of how the Virgin Mary is exalted for virtues men would like women to exhibit is Marina Warner, Alone of All Her Sex: The Myth of the Virgin Mary (New York, 1976). While I agree that Mary has been used against women who cannot be virgin and mother, I am arguing here that women have reclaimed her image in positive ways.

${ }^{56}$ Florence Nightingale, Cassandra (Old Westbury, N.Y., 1979), p. 53.
} 
God is female when she argued that "the desire to incarnate" in the true artist "is almost like the necessity of a woman to give birth to her child." ${ }^{57}$ From the blessed Lady who carries the new Bible of blank pages in H. D.'s Trilogy to Gertrude Stein's liturgical drama in praise of The Mother of Us All, modernist texts by women appear to corroborate the contemporary French feminist Hélène Cixous' sentiment that the woman writer sanctifies herself when she gives birth to "an amniotic flow of words that reiterates the contractual rhythms of labor." 58 Margaret Anderson and Jane Heap's desire for a radically new kind of art is brilliantly illustrated by the Little Review volume that consisted of sixty-four blank pages. ${ }^{59}$ The substitution of the female divinity for the male god, the womb for the penis, as the model of creativity was so pronounced by the turn of the century that it posed a real problem for such male modernists as T. S. Eliot, Lawrence, and Joyce. But of course, many women writers remained sensitive to the fact that such a mother-goddess myth was compensatory and that-unless freed from any biological imperative-it could entrap women in destructive stereotypes. To celebrate uniquely female powers of creativity without perpetuating destructive feminine socialization is the task confronted by writers as dissimilar as George Eliot, Rossetti, Schreiner, Wharton, H. D., and Mansfield, all of whom are involved in efforts to sanctify the female through symbols of female divinity, myths of female origin, metaphors of female creativity, and rituals of female power. "The Blank Page" is only one of many parables in an ongoing revisionary female theology. ${ }^{60}$

Since I have here persistently and perhaps perversely ignored history, I feel it is only fair to conclude by acknowledging that certain historical factors helped make this modulation in valuation possible. The shift in metaphors from the primacy of the pen to the primacy of the page is a late nineteenth-century phenomenon. The Romantic movement in poetry, the suffrage movement in politics, the rise of anthropology with its interest in fertility gods and goddesses, the myth of Mother Right coming at a time when the infant mortality rate was significantly lowered and birth control became more widely available, and finally

\footnotetext{
${ }^{57}$ Schreiner, From Man to Man, p. 453.

${ }^{58}$ Hélène Cixous, quoted by Verena Andermatt, "Hélène Cixous and The Uncovery of a Feminine Language," Women and Literature 7 (Winter 1979): 42.

${ }^{59}$ See Margaret Anderson, The Unknowable Gurdjieff(London, 1962), p. 75.

${ }^{60}$ Gilbert's two brilliant papers, "Potent Griselda: D. H. Lawrence's Ladybird and Literary Maternity" and "Soldier's Heart: Literary Men, Literary Women, and the Great War" (both unpublished), document the importance to women of rising anthropological theories of mother right and the significance of World War I to women writers. [Editor's note: Gilbert's papers were subsequently published in 1983 "Soldier's Heart: Literary Men, Literary Women, and the Great War", Signs, Vol. 8, No. 3, Women and Violence (Spring 1983): 422-450 and 1985: "Potent Griselda: The Ladybird and the Great Mother", D.H. Lawrence: A Centenary Consideration, Peter Balbert and Philip L. Marcus (eds.), Ithaca : Cornell UP: 130-61.]
} 
World War I-all of these need to be studied, for we are only just beginning to read the patterns and trace the figures in what all too recently has been viewed as nothing but the blank pages of women's cultural and literary history.

Denise Levertov expresses my own sense of excitement at engaging in such a task, even as she reminds us how attentive and patient we must be before the blank page to perceive genuinely new and sustaining scripts. Like Dinesen, moreover, Levertov seeks to consecrate her own repeated efforts to contribute to the blank pages of our future history. Recognizing that strenuous and risky readiness at the moment before conception is itself an art, a kind of balancing act, Levertov praises the discipline that allows the poet to stand firm on "one leg that aches" while upholding "the round table" of the "blank page." Such diligence receives its just reward when the round table of the blank page is transformed into living wood that sighs and sings like a tree in the wind. This attitude toward creativity substitutes for the artistic object an act or process. Furthermore, just as sexuality was previously identified with textuality, the text itself now becomes infused with potent sexual energy, or so Levertov claims in what we can now recognize as a decidedly female vision:

One at a time

books, when their hour is come

step out of the shelves.

Heavily step (once more, dusty, fingermarked,

but pristine!)

to give birth:

each poem's passion

ends in an Easter,

a new life.

The books of the dead

shake their leaves,

word-seeds fly and

lodge in the black earth. ${ }^{61}$

\footnotetext{
${ }^{61}$ Denise Levertov, "Growth of a Poet," The Freeing of the Dust (New York, 1975), pp. 83, 78-79. See also Susan Fromberg Schaeffer, "The Nature of Genres," Granite Lady (New York, 1974), p. 136.
} 